\title{
Antibacterial Activity of Oxolinic Acid on Pseudomonas glumae
}

\author{
Yasufumi HIKICHI ***
}

\begin{abstract}
Oxolinic acid (5-ethyl-5,8-dihydro-8-oxo[1,3]dioxolo[4,5-g] quinoline-7-carboxylic acid, Starner ${ }^{(B)}$ is a synthetic bactericide, developed from quinoline derivatives. Oxolinic acid completely inhibited the growth of gram negative bacteria including Pseudomonas glumae, $P$. plantarii, $P$. avenae, Erwinia carotovora subsp. carotovora and $E$. carotovora subsp. atroseptica at the concentration of $0.4 \mu \mathrm{g} / \mathrm{ml}$ or below in vitro. Oxolinic acid was effective against various isolates of $P$. glumae from rice grains collected from various districts of Japan. Antibacterial activities of oxolinic acid on $P$. glumae varied depending on the growth phase of the bacterium. Activity of oxolinic acid was bactericidal for the bacterium at the lag phase, but was bacteristatic for the bacterium at the early logarithmic phase and decreased after the middle logarithmic phase. Oxolinic acid sometimes induced abnormal elongation of $P$. glumae cells at the early logarithmic phase.
\end{abstract}

(Received September 22, 1992)

Key words : oxolinic acid, Pseudomonas glumae, growth phase, bactericidal activity.

\section{INTRODUCTION}

Oxolinic acid (5-ethyl-5,8-dihydro-8-oxo[1,3]dioxolo[4,5-g] quinoline-7-carboxylic acid, Starner ${ }^{\circledR}$, Fig. 1) is a synthetic bactericide developed for the control of bacterial disease on plants. Oxolinic acid is one of quinoline derivatives which have a high antibacterial activity against gram negative bacteria ${ }^{5,11}$. I have shown that oxolinic acid is effective for the control of bacterial grain rot of rice (Pseudomonas glumae), black leg of potato (Erwinia carotovora subsp. atroseptica), fire blight (E. amylovora) and soft rot (E. carotovora subsp. carotovora $)^{4}$. Oxolinic acid has been used in Japan for the control of bacterial seedling rot of rice ( $P$. glumae) in the form of seed treatment, and for the control of bacterial grain rot of rice ( $P$. glumae) and soft rot of vegetables ( $E$. carotovora subsp. carotovora) in the form of spray treatment.

Antibacterial activities of quinoline derivatives such as ciprofloxacin, nalidixic acid, pipedimic acid and miloxacin have been reported to be bactericidal ${ }^{1,2,6,8,12)}$. On the other hand, Zeiler ${ }^{13)}$ has reported that ciprofloxacin shows different antibacterial activities on Escherichia coli KL16 at the logarithmic phase and the stationary phase of the growth. I report here that antibacterial activity of oxolinic acid is either bactericidal or bacteristatic depending on the growth phase of $P$. glumae.

\section{MATERIALS AND METHODS}

Chemical. Oxolinic acid (technical compound, 99\%) was used throughout all experiments. Oxolinic acid was dissolved in $\mathrm{NaOH}$ solution whose concentration was three-tenth times that of oxolinic acid used in tests. There was no influence of $\mathrm{NaOH}$ at any concentration used in tests on the growth of $P$.

* Kasai Experimental Farm, Agricultural Science Research Laboratory, Takarazuka Research Center, Sumitomo Chemical Co., Ltd., Kishiro 636-2, Kasai-shi, Hyogo 675-23, Japan 住友化学工業 (株) 宝塚総合研究所農業科学研 究所加西試験農場

** Present address : Iwate Biotechnology Research Center, Narita 22-174-4, Kitakami, Iwate 024, Japan＼cjkstart現在： 岩手生物工学研究センター 


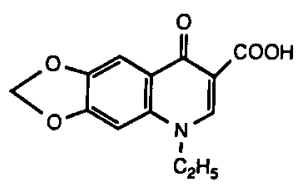

Fig. 1. Structure of oxolinic acid (5-ethyl-5,8-dihydro-8-[1,3]oxolo[4,5-g]quinoline-7-carboxylic acid, Starner ${ }^{(\mathbb{B})}$.

glumae.

Bacteria. Pseudomonas glumae Pg-4 was obtained from Ehime Prefectural Agricultural Experiment Station. Other isolates of $P$. glumae were isolated from rice grains collected from various districts of Japan, and were obtained from National Kyushu Agricultural Experiment Station. For the isolation of bacterium each grain was ground in a mortar and a pestle with $10 \mathrm{ml}$ of sterile water at room temperature. Aliquots $(0.1 \mathrm{ml})$ of the original solution and its 10 -fold dilution were dispensed onto S.PG selective medium ${ }^{10}$. Bacterial colonies were isolated after incubation for 2 days at $40^{\circ} \mathrm{C}$. Other bacteria used were obtained from Agricultural Science Research Laboratory, Takarazuka Research Center, Sumitomo Chemical Co., Ltd.

Minimum inhibitory concentration (MIC). Bacteria incubated overnight in peptone-yeast liquid medium (peptone: $5 \mathrm{~g}$, yeast: $2 \mathrm{~g}$, deionized water: 1 liter, $\mathrm{PY}$ medium) were suspended in PY medium to give the density ranging from $1 \times 10^{2}$ to $5 \times 10^{2}$ colony forming unit $(\mathrm{cfu}) / \mathrm{ml}$. Bacterial suspensions $(0.1$ $\mathrm{ml}$ ) were spread onto agar plates (Nutrient agar "Nissui" Nissui Seiyaku Co., Ltd) containing oxolinic acid at various concentration. MICs were determined based on colony emergence after incubation of $48 \mathrm{hr}$ at $30^{\circ} \mathrm{C}$.

Antibacterial Activity of oxolinic acid on growth of $P$. glumae. P. glumae Pg-4 was incubated for $24 \mathrm{hr}$ in PY medium and washed three times with PY medium by centrifugation at 5,000 rpm for $5 \mathrm{~min}$. Pellet was suspended in PY medium and the bacterial density was adjusted. Then oxolinic acid was added to the suspension to give the final concentration of 0.1 to $2.5 \mu \mathrm{g} / \mathrm{ml}$. The bacterial suspensions were incubated at $32^{\circ} \mathrm{C}$ for $24 \mathrm{hr}$. Serial dilutions of the bacterial suspension at various times after the onset of incubation were plated on Nutrient Agar plates and the bacterial density was determined by counting colonies after $48 \mathrm{hr}$ of incubation at $40^{\circ} \mathrm{C}$.

Antibacterial Activity of oxolinic acid on each phase of P. glumae growth. P. glumae Pg-4 at stationary phase was suspended in PY medium to give the bacterial density of $10^{6} \mathrm{cfu} / \mathrm{ml}$. The bacterial suspension was incubated at $32^{\circ} \mathrm{C}$ for $24 \mathrm{hr}$, and oxolinic acid was added at $0,6,9$ and $12 \mathrm{hr}$ after the onset of incubation to give the final concentration of $5 \mu \mathrm{g} / \mathrm{ml}$. The bacterial density at $24 \mathrm{hr}$ after the onset of incubation was determined by plating serial dilutions of the bacterial suspension on Nutrient Agar plates after $48 \mathrm{hr}$ of incubation at $40^{\circ} \mathrm{C}$.

\section{RESULTS}

\section{Minimum inhibitory concentration}

Oxolinic acid completely inhibited the growth of gram negative bacteria such as Enwinia spp. and some Pseudomonas spp. including $P$. glumae, $P$. avenae, $P$. plantarii and $P$. solanacearum at the concentration of $0.4 \mu \mathrm{g} / \mathrm{ml}$ while higher concentration of oxolinic acid was required to inhibit the growth of Xanthomonas spp. $(6.3 \mu \mathrm{g} / \mathrm{ml})$ and $P$. syringae $(25.0 \mu \mathrm{g} / \mathrm{ml})$ (Table 1). Sensitivity of bacteria to oxolinic acid was different among Pseudomonas spp.

Oxolinic acid also had strong antibacterial activity against 23 isolates of $P$. glumae and MIC was below $0.4 \mu \mathrm{g} / \mathrm{ml}$ (Table 2).

Antibacterial Activity on growth of $P$. glumae

When initial density of the bacterium was $2 \times 10^{8} \mathrm{cfu} / \mathrm{ml}$, the bacterial density decreased to $10^{3}$ to $10^{4}$ $\mathrm{cfu} / \mathrm{ml}$ during 3,6 and $9 \mathrm{hr}$ after incubation in the culture with $0.1,0.5$ and $2.5 \mu \mathrm{g} / \mathrm{ml}$ oxolinic acid (Fig. 2). Thereafter the bacterial densities in the cultures with 0.5 and $2.5 \mu \mathrm{g} / \mathrm{ml}$ oxolinic acid remained constant, 
Table 1. Antibacterial activity of oxolinic acid

\begin{tabular}{lc}
\hline \hline \multicolumn{1}{c}{ Bacteria } & $\mathrm{MIC}^{\prime}(\mu \mathrm{g} / \mathrm{ml})^{\mathrm{a})}$ \\
\hline Clavibacter michiganensis subsp. michiganensis & 25.0 \\
Curtobacterium flaccumfaciens pv. oortii & 25.0 \\
Agrobacterium tumefaciens & 6.3 \\
Envinia carotovora subsp. atroseptica & 0.4 \\
Erwinia carotovora subsp. carotovora & 0.4 \\
Envinia ananas & 0.4 \\
Pseudomonas avenae & 0.4 \\
Pseudomonas glumae & 0.4 \\
Pseudomonas plantarii & 0.4 \\
Pseudomonas solanacearum & 0.4 \\
Pseudomonas syringae pv. lachrymans & 25.0 \\
Pseudomonas syningae pv. maculicola & 25.0 \\
Pseudomonas syringae pv. tabaci & 25.0 \\
Xanthomonas campestris pv. campestris & 1.6 \\
Xanthomonas campestris pv. citri & 6.3 \\
Xanthomonas campestris pv. oryzae & 6.3 \\
Xanthomonas campestris pv. prini & 6.3 \\
Xanthomonas campestris pv. vesicatoria & 6.3 \\
\hline
\end{tabular}

a) Minimum inhibitory concentration.

Table 2. Antibacterial activity of oxolinic acid against isolates of $P$. glumae from rice grains collected from various districts of Japan

\begin{tabular}{lc}
\hline \hline \multicolumn{1}{c}{ Districts } & $\left.\mathrm{MIC}(\mu \mathrm{g} / \mathrm{ml})^{\mathrm{a}}\right)$ \\
\hline Yamagata Pref. Yahata-machi & 0.2 \\
Niigata Pref. - & 0.4 \\
Shizuoka Pref. Iwata-shi & 0.4 \\
Shizuoka Pref. Haibara-shi & 0.4 \\
Aichi Pref. Inazawa-shi & 0.4 \\
Aichi Pref. Nissin-cho & 0.4 \\
Gifu Pref. Gifu-shi & 0.4 \\
Gifu Pref. Ohno-cho & 0.4 \\
Shiga Pref. Kohra-cho & 0.4 \\
Shiga Pref. Kohoku-cho & 0.4 \\
Kyoto Pref. Fukuchiyama-shi & 0.4 \\
Wakayama Pref. Kanaya-cho & 0.4 \\
Tottori Pref. Aotani-cho & 0.4 \\
Tottori Pref. Nishihaku-cho & 0.4 \\
Shimane Pref. Tsuwano-cho & 0.4 \\
Kagawa Pref. Zentsuji-shi & 0.4 \\
Ehime Pref. Hohjoh-shi & 0.4 \\
Ehime Pref. Uwa-cho & 0.4 \\
Kohchi Pref. Ohtsuki-cho & 0.4 \\
Kohchi Pref. Nakamura-shi & 0.4 \\
Kohchi Pref. Tano-cho & 0.2 \\
Saga Pref. Karatsu-shi & 0.2 \\
Miyazaki Pref. Kitakata-cho & 0.1 \\
\hline a) Minima inhibitory concentration &
\end{tabular}

a) Minimum inhibitory concentration.

but the bacterial density in the culture with $0.1 \mu \mathrm{g} / \mathrm{ml}$ oxolinic acid started to increase after $12 \mathrm{hr}$ of incubation.

When initial density of the bacterium was $10^{8} \mathrm{cfu} / \mathrm{ml}$, the bacterial density decreased to $10^{4}$ and $10^{6}$ during 6 and $9 \mathrm{hr}$ after incubation in the culture with 0.1 and 0.5 or $2.5 \mu \mathrm{g} / \mathrm{ml}$ oxolinic acid (Fig. 2). And 

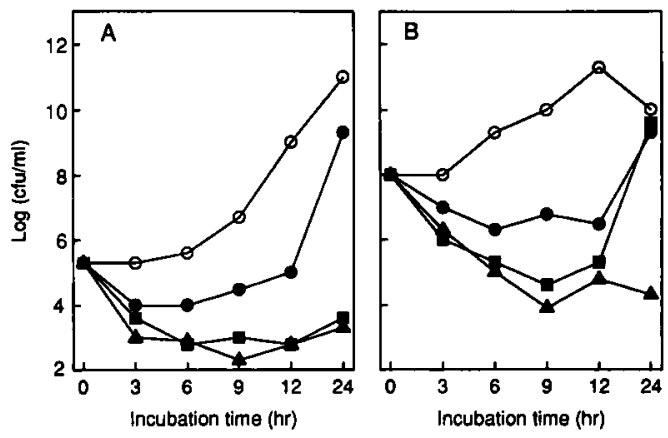

Fig. 2. Antibacterial activity of oxolinic acid on P. glumae Pg-4 in liquid culture. A: Initial density of the bacterium was $2 \times 10^{5} \mathrm{cfu} / \mathrm{ml}$. B: Initial density of the bacterium was $1 \times 10^{8} \mathrm{cfu} / \mathrm{ml}$. Concentration of oxolinic acid: $O$, untreated control; $\bullet, 0.1 \mu \mathrm{g} / \mathrm{ml} ; \mathbf{D}, 0.5 \mu \mathrm{g} / \mathrm{ml} ; \Delta, 2.5 \mu \mathrm{g} / \mathrm{ml}$.

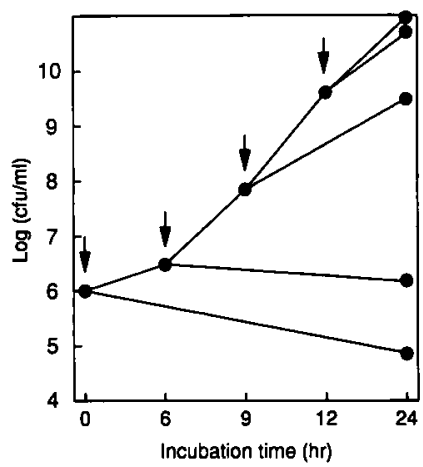

Fig. 3. Antibacterial activity of oxolinic acid on $P$. glumae $\mathrm{Pg}-4$ at different growth phases. Oxolinic acid was added at $0,6,9$ or $12 \mathrm{hr}$ after the onset of incubation to the final concentration of $5 \mu \mathrm{g} / \mathrm{ml}$. Arrows indicate application time with oxolinic acid.

the bacterial densities increased after $12 \mathrm{hr}$ of incubation in the culture with 0.1 and $0.5 \mu \mathrm{g} / \mathrm{ml}$ oxolinic acid, but not in the culture with $2.5 \mu \mathrm{g} / \mathrm{ml}$ oxolinic acid.

$P$. glumae cells sampled at each time point after treatment with oxolinic acid were tested for their sensitivity to oxolinic acid. All bacterial cells did not form colony on agar plates containing $0.4 \mu \mathrm{g} / \mathrm{ml}$ oxolinic acid.

\section{Antibacterial activity on different growth phases of $P$. glumae}

The bacterial density $\left(10^{6} \mathrm{cfu} / \mathrm{ml}\right)$ at the onset of incubation decreased to $7 \times 10^{4} \mathrm{cfu} / \mathrm{ml}$ after $24 \mathrm{hr}$ of incubation in the culture with $5 \mu \mathrm{g} / \mathrm{ml}$ oxolinic acid. When oxolinic acid was applied at the early logarithmic phase ( $6 \mathrm{hr}$ after incubation), the growth of bacterium was inhibited and the bacterial density remained $2 \times 10^{6} \mathrm{cfu} / \mathrm{ml}$ after $24 \mathrm{hr}$ of incubation (Fig. 3). On the other hand, oxolinic acid had little antibacterial activity when it was applied at 9 and $12 \mathrm{hr}$ after incubation (after the middle logarithmic phase) when the bacterial densities were $3 \times 10^{9}$ and $5 \times 10^{10}$, respectively.

\section{DISCUSSION}

Generally, quinoline derivatives are reported to have bactericidal activity ${ }^{1,2,6,8,12}$. On the other hand, $Z_{\text {Ziler }}{ }^{13)}$ has reported that ciprofloxacin, one of the quinoline derivatives, shows different antibacterial 


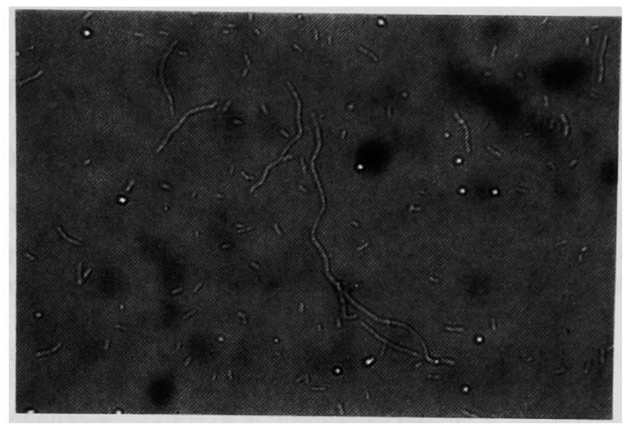

Fig. 4. Abnormal elongation of $P$. glumae $\mathrm{Pg}-4$ cells treated with oxolinic acid at the concentration of $5 \mu \mathrm{g} /$ $\mathrm{ml}$. The bacterium at the initial density of $10^{8} \mathrm{cfu} / \mathrm{ml}$ was incubated at $32^{\circ} \mathrm{C}$ in $\mathrm{PY}$ medium containing $5 \mu \mathrm{g} / \mathrm{ml}$ of oxolinic acid for $24 \mathrm{hr}$.

activities on $E$. coli KL16 depending on its growth phases. Bactericidal activity of ciprofloxacin on $E$. coli $\mathrm{KL} 16$ at the logarithmic phase is strong and rapid, while that at the stationary phase is weak and slow. But activity of ciprofloxacin on $E$. coli Neumann at any growth phase is bactericidal. And the pattern seen with $E$. coli $\mathrm{KL} 16$ seems to be rare in the observation of clinical isolates of $E$. coli. The present results demonstrated that the antibacterial activity of oxolinic acid was also different depending on the growth phase of $P$. glumae. But in contrast with activity of ciprofloxacin on $E$. coli KL16, activity of oxolinic acid on $P$. glumae at the lag phase was bactericidal and that at the early logarithmic phase was bacteristatic. And oxolinic acid showed little antibacterial activity on $P$. glumae after the middle logarithmic phase.

$S$ ith $^{2,8}$ has reported on lower bactericidal activity of nalidixic acid on $E$. coli KL16 and one curious feature of this activity, whose $E$. coli KLl6 treated with nalidixic acid commenced to elongate abnormally. In this test, I observed similar abnormal elongation of $P$. glumae cells. When initial density of the bacterium was $10^{8} \mathrm{cfu} / \mathrm{ml}$, the bacterial cells elongated abnormally with $0.5 \mu \mathrm{g} / \mathrm{ml}$ oxolinic acid (Fig. 4). I could not observed a septum in the elongating cells. After the elongating cells were incubated in PY medium without oxolinic acid for $24 \mathrm{hr}$, no elongation cells were observed. The emergence of elongating cells of $P$. glumae at the early logarithmic phase may result from inhibition of cell division by oxolinic acid. Activity of oxolinic acid was bacteristatic for the bacterium at the early logarithmic phase, and the cell division of the treated bacterium was inhibited and the cells were still alive. So the bacterial cells may elongate abnormally.

Quinoline derivatives inhibit DNA gyrase activity which introduces negative supercoils into bacterial DNA $^{3,7,99}$. Inhibition of DNA gyrase activity leads to inhibition of DNA reproduction and cell division in the bacterium, leading to death of the bacterium. Therefore antibacterial activity of quinoline derivatives is thought to be bactericidal. However, in this test, bactericidal activity of oxolinic acid on $P$. glumae depended on the growth phase of the bacterium. Results presented here suggested that antibacterial activity of oxolinic acid depended on not only inhibition on DNA gyrase activity but also many factors in sensitivity of the bacterium to the chemical, that is, growth phase of the bacterium, population of the bacterium and permeability of the chemical in the bacterial cell membrane. Further studies are necessary to clarify the relationship of antibacterial activity of oxolinic acid with inhibition on DNA gyrase activity and these factors.

I wish to thank Dr. T. Okuno, Kyoto University, for his critical reading for the manuscript.

\section{Literature cited}

1. Barry, A.L., Jones, R.N., Thornsberry, C., Ayers, L.W., Gerlach, E.H. and Sommers, H.M. (1984). Antibacterial activities of ciprofloxacin, norfloxacin, oxolinic acid, cinoxacin and nalidixic acid. Antimicrob. Agents Chemother. $25: 633-637$.

2. Crumplin, G.C. and Smith J.T. (1975). Nalidixic acid: An antibacterial paradox. Antimicrob. Agents 
Chemother. $8: 251-261$.

3. Gellert, M., Mizuuchi, K., O'Dea, M.H., Itoh, T. and Tomizawa, J. (1977). Nalidixic acid resistance: A second genetic character involved in DNA gyrase activity. Pro. Natl. Acad. Sci. USA $74:$ 4772-4776.

4. Hikichi, Y., Noda, C. and Shimizu, K. (1989). Oxolinic acid. Jpn. Pestic. Inf. 55 : 21-23.

5. Kaminsky, D. and Melzer, R.I. (1968). Quinoline antibacterial agents. Oxolinic acid and related compounds. J. Med. Chem. 11: 160-163.

6. Obana, Y., Maya, Y. and Nishino T. (1980). Lowering of the bactericidal action by exposure to high concentrations of nalidixic acid, pipedimic acid and miloxacin. Chemotherapy $28: 1171-1178$ (in Japanese).

7. Shen, L.L. and Pernet, A.G. (1985). Mechanism of inhibition of DNA gyrase by analogues of nalidixic acid: The target of the drugs is DNA. Proc. Natl. Acad. Sci. USA $82: 307-311$.

8. Smith, J.T. (1984). Awakening the slumbering potential of the 4-quinoline antibacterials. The Pharmaceutical J. $15: 299-305$.

9. Sugino, A., Peebles, C.L., Kreuzer, K.N. and Cozzarelli, N.R. (1977). Mechanism of action of nalidixic acid: Purification of Escherichia coli nalA gene product and its relationship to DNA gyrase and a novel nicking-closing enzyme. Proc. Natl. Acad. USA 74: 4767-4771.

10. Tsushima, S., Wakimoto, S. and Mogi, S. (1986). Medium for detecting for Pseudomonas glumae Kurita et Tabei, the casual bacterium of grain rot of rice. Ann. Phytopath. Soc. Japan $52: 253-259$ (in Japanese).

11. Turner, F.J., Ringel, S.M., Martin, J.F., Storino, P.J., Daly, J.M. and Schwartz, B.S. (1967). Oxolinic acid, a new synthetic antimicrobial agent I. in vitro and in vivo activity. Antimicrob. Agents Chemother. $7: 475-479$.

12. Yamashita, S., Yajima, H. and Mitsuhashi S. (1985). Antibacterial activity of BAYo9867. Chemotherapy 33: 1-17 (in Japanese).

13. Zeiler, H.J. (1985). Evaluation of the in vitro bactericidal action of ciprofloxacin on cells of Escherichia coli in the logarithmic and stationary phases of growth. Antimicrob. Agents Chemother. $28: 524-527$.

和 文 摘 要

曳地康史：Pseudomonas glumaeに対するオキソリニック酸の抗菌特性

キノリン系合成化合物であるオキソリニック酸 (5-ethyl-5,8-dihydro-8-oxo[1,3]dioxolo[4,5·g]quinoline-7carboxylic acid, スターナ®)は, 植物病原細菌のうちグラム陰性細菌, とくにPseudomonas glumae, P. plantani， $P$. avenae, $P$. solanaceanum などの Pseudomonas 属菌や Envinia 属菌に高い抗菌活性を示した。P. glumae 各分噰 株に対するオキソリニック酸の MIC は 0.1-0.4 $\mu \mathrm{g} / \mathrm{ml}$ であった。その作用性は, 誘尊期に対しては殺菌作用が強く, 対数增殖期初期に対しては增殖抑制効果が強いが，対数増殖中期以降に対する効力は低いことが明らかとなった。ま た，オキソリニック酸処理によって，P. glumae の細胞形が異常に伸長する現象が認められた。 